\title{
Andragogy Based E-learning Model for Early Childhood Teachers in West Java
}

\author{
Nurul Fahimah*, Ace Suryadi, Asep Saepudin \\ Department of Community Education \\ Universitas Pendidikan Indonesia \\ Bandung, Indonesia \\ *niar72@upi.edu, acesuryadi@upi.edu
}

\begin{abstract}
This research is aimed to develop the e-learning training model using andragogy approach for PAUD Teachers in West Java province. This research is conducted involving 240 PAUD teachers taken by simple randomized sample from training participants from 6 cities in West Java. The feasibility study data (Performance and e- learning design) has resulted from the questionnaire which will later on be analyzed descriptively considering the score percentage and feasibility category.
\end{abstract}

Keywords - training, e-learning, andragogy

\section{INTRODUCTION}

Various research results have confirmed that quality early childhood education (PAUD) programs have a positive impact on a child's academic and social emotional abilities in the future $[1,2]$. Besides having a positive impact on the individual children, a quality PAUD program also contributes socioeconomic benefits to a community and a country. Vandenbroecka et al. in their analytical report states that early childhood education not only can improve life quality for children and families in the future but also provide socioeconomic benefits for the community and government [3].

In addition, Alderman [4] also states that early childhood education is the major investment in a strategy to reduce poverty transmission from insufficient parents to their children. This can reinforce the opinion that investment for children's welfare is a foundation to achieve sustainable development, in accordance with one of the 2030 Sustainable Development Goals (SDGs) i.e. all children have the right to have access to sustainable development, care, and qualified education so that children can grow and develop to shape humans adult who contribute to families and communities.

Responding to this agenda, one of the steps taken by the Ministry of Education and Culture of the Republic of Indonesia (Kemendikbud RI), is by establishing children's education as a national priority program contained in the 20202024 Medium-Term National Development Plan (RPJMN). The government strives to increase the quantity and quality of early childhood education in Indonesia. As seen in the SDGs
Baseline Report on children in Indonesia released by Bappenas [5], data is obtained that as much as 72 percent of the population of 6-year- olds have participated in the PAUD program. These data illustrate that the enrollment rate of children in early childhood education is quite high, but the growth in the participation rate must also be accompanied by a growth in the quantity and quality of adequate PAUD services.

Important efforts need to be made to stimulate the quality of PAUD in Indonesia so that the SDGs target in 2030 is achieved, one of which is by improving the quality of PAUD teachers. Based on the data obtained from the management of PAUD Dikmas Kemendikbud for the 2019-2020 academic year, there are 203,488 non-formal PAUD units throughout Indonesia with 5,691,201 students served by 431,215 PAUD teachers. West Java as the second province with the highest number of PAUD units in Indonesia has 28,723 PAUD units consisting of formal and non-formal PAUD [6].

However, the great number of units has not been matched by the adequate quality of PAUD teachers, it can be seen based on national data obtained from the Dapodik of the Directorate General of Early Childhood Education and the Dikmas that more than half of non-formal PAUD teachers in Indonesia (215,516 people), especially West Java $(32,822$ people) have not yet taken S1 education. and more than 90 percent of PAUD teachers in Indonesia are graduates of non-PAUD Teacher Education study programs.

In addition, Dapodik data also shows that as many as 65.82 percent of PAUD educators in Indonesia have not yet taken S1 education. This can also be seen in West Java, where most of the non-formal PAUD educators in West Java graduated from high school (SMA). Based on the data presented, it can be concluded that most PAUD teachers in Indonesia do not have an educational background yet that can support their competence. Thus, providing training is an effort that can be carried out to encourage the improvement of the competence of early childhood teachers.

The government has currently made efforts by providing training for PAUD teachers, both face-to-face and online training, but this training is still limited and has not been able 
to reach all PAUD teachers. It can be seen from the achievements of the tiered training participants until 2019 faceto-face training participants were only able to reach 200,528 participants, while for online training in 2018 it was only able to recruit 4,223 participants [7].

The minimum of online education and training achievements occurs since there are several obstacles, including the organizing cost is quite expensive, limited participant quota, limited material, and have to be done through video conference at a specified time so that participants cannot freely determine their learning time. Therefore, andragogybased e-learning training for PAUD teachers can be a solution as this training has several advantages i.e. 1) more affordable and efficient operating costs; 2) the quota of participants is unlimited so that it can reach more targets and a wider area; 3 ) accessible to various internet connected media; 4) more flexible training time as the material is available and can be studied offline (offline) and can be repeated at any time; 5) more widely available material, not only training material but also other materials that support teacher competence.

In addition to the constraints that cause limited number of PAUD teachers who have participated in improving professional competencies training, there are also obstacles that hinder the effectiveness and efficiency of the learning process for PAUD teachers, which is based on data obtained from PAUD statistics 2019/2020 shows that most PAUD teachers age in West Java is in the age range of 30 to 49 years even some are in the age range of 50 to 59 years. These characteristics are important to consider in developing an elearning model given that adult learning is different from children learning [8].

This e-learning training model is expected to meet the learning needs of adults with the flexibility offered, so that trainees are free to determine the materials they want to learn, the learning time and the desired learning load. Referring to this, this study aims to develop an andragogi-based e-learning training model for PAUD teachers in West Java Province.

\section{A. Training}

According to Greenberg [9] training is a process where people systematically acquire and improve the skills and abilities needed to improve their performance. In line with Decenzo and Robbins [10] training is more present- oriented, the focus is on the individual's current job, specific skills and abilities to immediately do their job. Meanwhile, pursuant to Dessler [11] training means giving new workers and old workers the skills they need to do their jobs. As stated by Williams [12] training means providing opportunities for individuals to develop specific job skills, experience and knowledge they need to do their jobs or improve their performance. Longnecker and LFink in the book Ivancevich and Konopaske [13] explain that training is a systematic process of changing worker behavior in the direction of achieving organizational goals.
Training is related to present job skills and abilities. Training has a current orientation and helps individuals master certain skills and abilities needed to be successful. The above definitions conclude that training is a planned effort by an organization to facilitate the learning of work-related behaviors.

\section{B. E-learning}

In simple terms, Ellis, et al. [14] define e-learning as information and communication technology that is used to support students in improving their learning. Likewise, with Arkorful and Nelly [15] who state that e-learning is an online course whose process depends on and is supported by web services in providing and supporting the educational processes.

This is supported by Sangra et al. [16] who define elearning as an approach to teaching and learning that is applied and is based on the use of media and or electronic devices as a tool to improve access to training, communication and interaction and is the adoption of new models of how to understand and develop learning.

A similar opinion was also expressed by Alonso et al. [17] who stated that e-learning is the use of new multimedia technologies and the Internet to improve the quality of learning by facilitating access to resources and services as well as enabling long distance exchange and collaboration. Bermejo [18] also states that e-learning is an education that uses a computerized communication system as an environment for communication, information exchange and interaction between students and instructors. Further, Snell and Bohlander [19] mention that e-learning is an audiovisual program and computer-oriented training methods that include various applications such as web and computer-based training and virtual classes. E-learning transforms the learning process in a number of possible ways to make training more efficient and cost-effective.

In addition, Ruth and Kapar [20] define e-learning as learning that is facilitated by various technological networks through various digital devices that allow the learning process to occur anytime and anywhere. Based on the various definitions above, it can be concluded that e-learning is learning whose delivery mediated by electronic technology which aims to influence knowledge construction by referring to the personal experiences, practices and knowledge of students. E-learning includes applications such as web and computerbased training and virtual classes. This makes it possible to conduct training more efficient and effective cost.

\section{Andragogy}

According to Knowles in Blondy [21] adult learning is different from children learning, there are five assumptions used in adult learning. Those are: self-concept i.e. when a person becomes an adult, his self-concept changes from the individual who depend on someone being an independent human being; experience i.e. when the individual becomes an adult, the individual has a collection of experiences that 
continues to grow which becomes an increasing source of learning; readiness to learn i.e. adult individuals are assumed to have mature learning readiness, learning readiness is no longer an academic demand but is more determined by demands for development and changes in tasks and social roles; learning orientation i.e. adult learning orientation is no longer like children who are centered on mastering learning material, but their learning orientation is centered on solving the problems encountered. This is caused by the tendency to learn for adults leads to the need to deal with problems faced in daily life, especially in relation to adult social tasks and roles; motivation to learn, i.e. the motivation to learn that adults have comes from the internal individual (intrinsic motivation) who can survive in completing learning tasks without any external pressure. Adults have the freedom to continue learning activities or postpone them, as well as stop other activities in order to continuing learning activities.

Arghode et. al [22] states that andragogy theory is an adult learning theory which believes that adults are independent learners and learn through experience, adults also want to be able to apply their learning result immediately, and adults learn at best when they choose content and learning methods alone. $\mathrm{He}$ also describes the implications in online learning instructions that can be carried out i.e. creating online discussion forums to encourage self-directed learning, designing online instruction to provide unique learning opportunities, giving students the flexibility to learn at their own pace, through blogs, online activities, videos can help online teachers design activities to encourage independent learning.

Cercone [23] explains that in online learning with adult students, there are several things that online learning instructors need to understand, including that self-direction, flexibility, and the learning process are things that need to be emphasized more than content. Instructors have to recognize that adults are different from children and require a special approach to learning. In addition, there are several characteristics of adults that need to be understood as they will affect the learning process i.e. that adult learners must be seen as a whole person and should be considered more than just processors of cognitive information. They come with thoughts, memories, conscious and subconscious worlds, feelings, beliefs, imaginations, and a physical body, all of which can relate to the new learning they will acquire. It is very important for educators to understand that culture and society affect each individual differently. Then the learning process is more than just the acquisition and storage of new organized information. The learning process involves learning about oneself and changing not only what is learned, but also the way people learn. Educators also need to be able to feel, visualize, understand, and learn informally with others. These emphasize that in facilitating adult learning there needs to be interaction and collaboration

\section{METHODS}

This research employed development research used to develop and validate an educational product conducted cyclically with stages, analysis, design, development, implementation, and evaluation. The cyclical process is called ADDIE [24] as the following pattern in Figure 1 below.

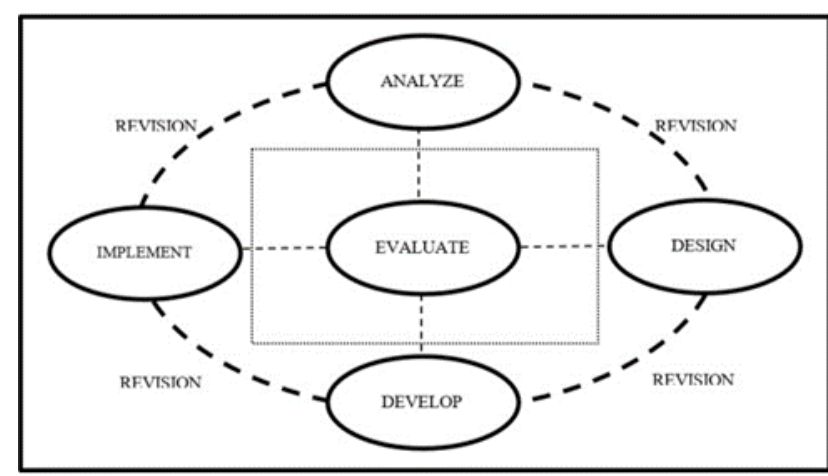

Fig. 1. ADDIE Model development chart [25].

This study developed a model of andragogy-based etraining for PAUD teachers. This will be tested in two stages i.e. the initial field test will involve 100 PAUD teachers, while the major field test will be carried out on 240 PAUD teachers i.e. 40 teachers training participants in six cities and districts in West Java (Bekasi City and Regency, Karawang Regency, Depok City, Bandung City, Bogor City, and Purwakarta Regency). The location was chosen in addition to the ease of access and affordability of researchers, based on the data of the Directorate of GTK Kemendikbud in 2019 the regions are the areas with the highest number of training participants in West Java Province.

The data will be taken in the form of feasibility study results that will be assessed by experts as well as trainees. Feasibility studies will be conducted on the materials provided, the media developed, and the overall andragogy-based elearning model. The data will be obtained with questionnaires to be filled out by experts and trainees who will then be analyzed using descriptive statistics to see the percentage that describes the feasibility scale. The feasibility category in this study will be measured using the Likert scale. The Likert scale used in this study has a score range of one to five, i.e.: $1=$ absolutely inappropriate; 2 = inappropriate; $3=$ slightly appropriate; $4=$ appropriate; and $5=$ absolutely appropriate. The total appropriateness score will then be percentage and categorized according to the above five categories. The feasibility scale is based on the percentage of the score i.e.: $\leq$ $20 \%=$ absolutely inappropriate; $21 \%-40 \%=$ inappropriate; $41 \%-60 \%=$ slightly appropriate; $61 \%-80 \%=$ appropriate; $81 \%-100 \%=$ absolutely appropriate 


\section{FINDINGS AND DISCUSSION}

\section{A. The Implementation of Andragogy-based E-Learning}

The development of this andragogy-based e-learning model was developed through several stages i.e. needs analysis by conducting research and gathering information related to the characteristics of learning objectives, planning and developing the model, conducting field trials. The needs analysis carried out in this study is an analysis of user needs and technical specification requirements. The analysis of user needs has to be carried out in the implementation of e-learning system in order for the implementation of the media to be targeted and can be functioned properly as a learning media.

In accordance with the observation of adult users' needs analysis who need freedom in learning both in terms of time, materials, and methods, then the necessary system needs is an E- Learning system that can be accessed online at any time, has the ability to update the content of materials and displays, can be used for task management and quizzes, and users can manage their own E-Learning system for the learning process by following the structure that has been created.

The technical specification analysis stage is done to know the requirements that must be met to access the E-Learning system developed. to access E-Learning a Pentium III computer is required. In addition, it is also necessary for operating systems such as Windows XP (or other operating systems) that feature Office applications, Adobe/Pdf Reader, Web Browser (Internet Explorer, Mozilla Firework, Opera and others) and other supporting applications. Each of these computers must be connected to an internet network.

Once the data at the analysis stage is collected then the next stage is to create a design. The design stages are: domain name and hosting; The display design of the E-Learning system which is a sketch of the E-Learning system to be developed that describes the location of parts of the E-Learning system; the design of a lesson/course material page that will display the topic of material adjusted to the amount per Basic competency. Each material can be downloaded in the form of pdf and word files that will be equipped with quizzes and tasks in the form of offline, online, and other assignments.

\section{B. E-learning Feasibility Test}

In the development and implementation stages of the eLearning system, several tests are needed to assess the feasibility of the e-learning model that has been created. Feasibility assessment is carried out through several stages i.e. testing material experts and learning media experts as well as by PAUD teachers as training participants.

Before e-Learning is tested on PAUD teacher training participants, it is necessary to test it by a validator consisting of material experts and media experts. The data obtained shows the feasibility level of the e-Learning system as a learning media. The suggestions provided on the instrument are used for consideration of further media improvement. Assessment by material experts is carried out using an assessment questionnaire given to material experts. The assessment is viewed from the aspect of material quality and benefits. The percentage of material expert judgment data is presented in table 1 .

TABLE I. DATA ON THE RESULTS OF THE FEASIBILITY ASSESSMENT OF TRAINING MATERIALS

\begin{tabular}{|l|l|}
\hline \multicolumn{1}{|c|}{ Aspect } & \multicolumn{1}{c|}{ Percentage (\%) } \\
\hline Material Quality & 87.27 \\
\hline Benefit & 80.00 \\
\hline Average & 85.33 \\
\hline
\end{tabular}

The data shows that judging by the material quality aspect, the results of the expert assessment showed a percentage of $87.27 \%$, while for material benefit aspects, experts gave a percentage assessment of $80.00 \%$. Overall e-learning system validation rate based on material expert assessment gained a percentage of $85.33 \%$. The percentage shows that the ELearning system developed is well worth using according to the advice and revision of the material expert.

Furthermore, the assessment is carried out by media experts, the assessment is also carried out using the assessment questionnaire given to the media expert. Assessments are reviewed from aspects of system performance and E-Learning design. The data on the results of the learning media expert's assessment are presented in table 2 .

TABLE II. DATA ON THE RESULTS OF THE LEARNING MEDIA EXPERT'S ASSESSMENT

\begin{tabular}{|l|l|}
\hline \multicolumn{1}{|c|}{ Aspect } & Percentage (\%) \\
\hline E-Learning performance & 95.00 \\
\hline Design & 92.50 \\
\hline Total & 93.75 \\
\hline
\end{tabular}

The data in the table shows that judging by performance pects, e-Learning systems developed get a percentage of $95 \%$ and are reviewed from the design aspect get a percentage of $92.25 \%$. Overall the level of validation of learning media against the E-Learning system from the assessment of media experts gained a percentage of $93.75 \%$. The percentage indicates that the developed e-learning system is very feasible to be used with some revisions.

After going through a feasibility test by material and media experts, the developed e-learning system will be tested on PAUD teachers in West Java who are registered as training participants. The testing phase is carried out by logging into the E-Learning system as a user by accessing the domain name address on the browser page. The following is a table of test results on the E-Learning system. The results of system testing conducted by training participants are presented in table 3 . 
TABLE III. DATA ON THE RESULTS OF THE E-LEARNING SYSTEM FEASIBILITY TEST BY PAUD TEACHERS WHO ARE TRAINING PARTICIPANTS IN WEST JAVA

\begin{tabular}{|l|l|l|}
\hline No. & \multicolumn{1}{|c|}{ The function tested } & Percentage (\%) \\
\hline 1 & Access to domain name address & 99 \\
\hline 2 & Login as User & 98 \\
\hline 3 & Access to E- Learning the front page & 96 \\
\hline 4 & Access to course categories & 93 \\
\hline 5 & Access to Web Design course & 92 \\
\hline 6 & Download material & 99 \\
\hline 7 & Access to quizzes and answers & 83 \\
\hline 8 & $\begin{array}{l}\text { Access to assignments and upload files on } \\
\text { assignments }\end{array}$ & 87 \\
\hline 9 & User Log off & 100 \\
\hline Average & 94.11 \\
\hline
\end{tabular}

The test results showed that all functions in E-Learning were able to function properly, which was shown by the results of the training participant scoring data of $94.11 \%$. the percentage indicates that the developed e-learning system models are well worth using. The summary of the assessment results of the experts and trainees is described in the following diagram:

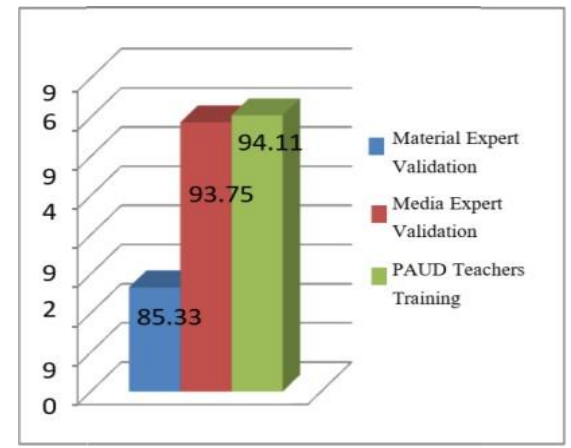

Fig. 2. E-Learning validation level bar chart by experts and training participants

Figure 2 shows that in every aspect of the assessment from the material expert, the learning media expert and the student get a high score. Thus, the andragogy-based e-learning model developed is feasible to be implemented.

\section{CONCLUSION}

The development of this andragogy-based e-learning model was developed through several stages, namely needs analysis by conducting research and gathering information related to the characteristics of learning objectives, planning and developing models, conducting initial field trials, revisions and primary field trials. The primary field test to assess the feasibility of andragogy-based e-learning as a learning media was carried out by validation of material experts, learning media experts and training participants. The feasibility level of the material expert earned a percentage of $85.33 \%$ with a very feasible category. The level of feasibility from learning media experts earned a percentage of $93.75 \%$ with a very feasibility category and the amount of feasibility level of the training participants gained a percentage of $94.11 \%$ with a very feasible category. Thus the andragogy-based e-learning model has met the feasibility standards according to predetermined criteria

\section{ACKNOWLEDGMENT}

Our gratitude goes to Prof. supervisor. Hufad and Dr. Nike Kamarubiani, M.Pd, as our supervisors, who have provided alot of guidance, input and, assistance so that we can conduct this research optimally.

\section{REFERENCES}

[1] W. S. Barnett, "Long-term effects of early childhood programs on cognitive and school outcomes," Futur. Child., pp. 25-50, 1995.

[2] L. Bakken, N. Brown, and B. Downing, "Early childhood education: The long-term benefits," J. Res. Child. Educ., vol. 31, no. 2, pp. 255 269, 2017.

[3] M. Vandenbroeck, K. Lenaerts, and M. Beblavý, "Benefits of early childhood education and care and the conditions for obtaining them," Eur. Expert Netw. Econ. Educ., vol. 32, pp. 1-86, 2018.

[4] H. Alderman, No small matter: The impact of poverty, shocks, and human capital investments in early childhood development. The World Bank, 2011.

[5] Badan Perencanaan Pembangunan Nasional (Bappenas) dan United Nations Children's Fund, Laporan Baseline SDG tentang Anak-Anak di Indonesia. Jakarta: BAPPENAS dan UNICEF, 2017.

[6] Dikmas Dapodik of the Directorate General of Early Childhood Education and the, No Title. 2019.

[7] PP-PAUD and Dikmas West Java, Providing training for PAUD teachers offline and face to face. 2018.

[8] Pusdatin Kemendikbud Indonesia, Statistik Pendidikan Anak Usia Dini 2019/2020. Jakarta: Pusat Data dan Teknologi Informasi, 2020.

[9] J. Greenberg, Managing Behavior in Organization. New Jersey: Pearson Education, Inc., 2010.

[10] DeCenzo, D. A., Robbins, S. P., Human Resource Management. New York: John Wiley \& Sons, Inc., 2002.

[11] Gary Dessler, Human Resource Management. New Jersey: Pearson Education, Inc., 2011.

[12] P. T. Williams, Waste treatment and disposal. John Wiley \& Sons, 2005.

[13] John M Ivancevich and Robert Konopaske, Human Resource Management. New York: Mc Graw Hill, 2013.

[14] R. A. Ellis, P. Ginns, and L. Piggott, "E-learning in higher education: some key aspects and their relationship to approaches to study," High. Educ. Res. Dev., vol. 28, no. 3, pp. 303-318, 2009.

[15] V. Arkorful and N. Abaidoo, "The role of e-learning, advantages and disadvantages of its adoption in higher education," Int. J. Instr. Technol. Distance Learn., vol. 12, no. 1, pp. 29-42, 2015.

[16] A. Sangrà, D. Vlachopoulos, and N. Cabrera, "Building an inclusive definition of e-learning: An approach to the conceptual framework," Int. Rev. Res. Open Distrib. Learn., vol. 13, no. 2, pp. 145-159, 2012.

[17] F. Alonso, G. López, D. Manrique, and J. M. Viñes, "An instructional model for web-based e-learning education with a blended learning process approach," Br. J. Educ. Technol., vol. 36, no. 2, pp. 217-235, 2005.

[18] S. Bermejo, "Cooperative electronic learning in virtual laboratories through forums," IEEE Trans. Educ., vol. 48, no. 1, pp. 140-149, 2005.

[19] S. Snell and G. Bohlander, Human Resource Management. Ohio: Thomson Learning, 2007.

[20] M. Rüth and K. Kaspar, "The E-Learning Setting Circle: First Steps Toward Theory Development in E-Learning Research," Electron. J. eLearning, vol. 15, no. 1, pp. pp94-104, 2017. 
[21] L. C. Blondy, "Evaluation and application of andragogical assumptions to the adult online learning environment," J. Interact. online Learn., vol. 6, no. 2, pp. 116-130, 2007.

[22] V. Arghode, E. W. Brieger, and G. N. McLean, "Adult learning theories: implications for online instruction," Eur. J. Train. Dev., vol. 41, no. 7, 2017.
[23] K. Cercone, "Characteristics of adult learners with implications for online learning design,” AACE J., vol. 16, no. 2, pp. 137-159, 2008.

[24] N. Aldoobie, “ADDIE Model,” Am. Int. J. Contemp. Res., vol. 107, no. 3, pp. 361-373, 2015.

[25] R. M. Branch, Instructional design: The ADDIE approach, vol. 722. Springer Science \& Business Media, 2009. 